Provided for non-commercial research and education use. Not for reproduction, distribution or commercial use.

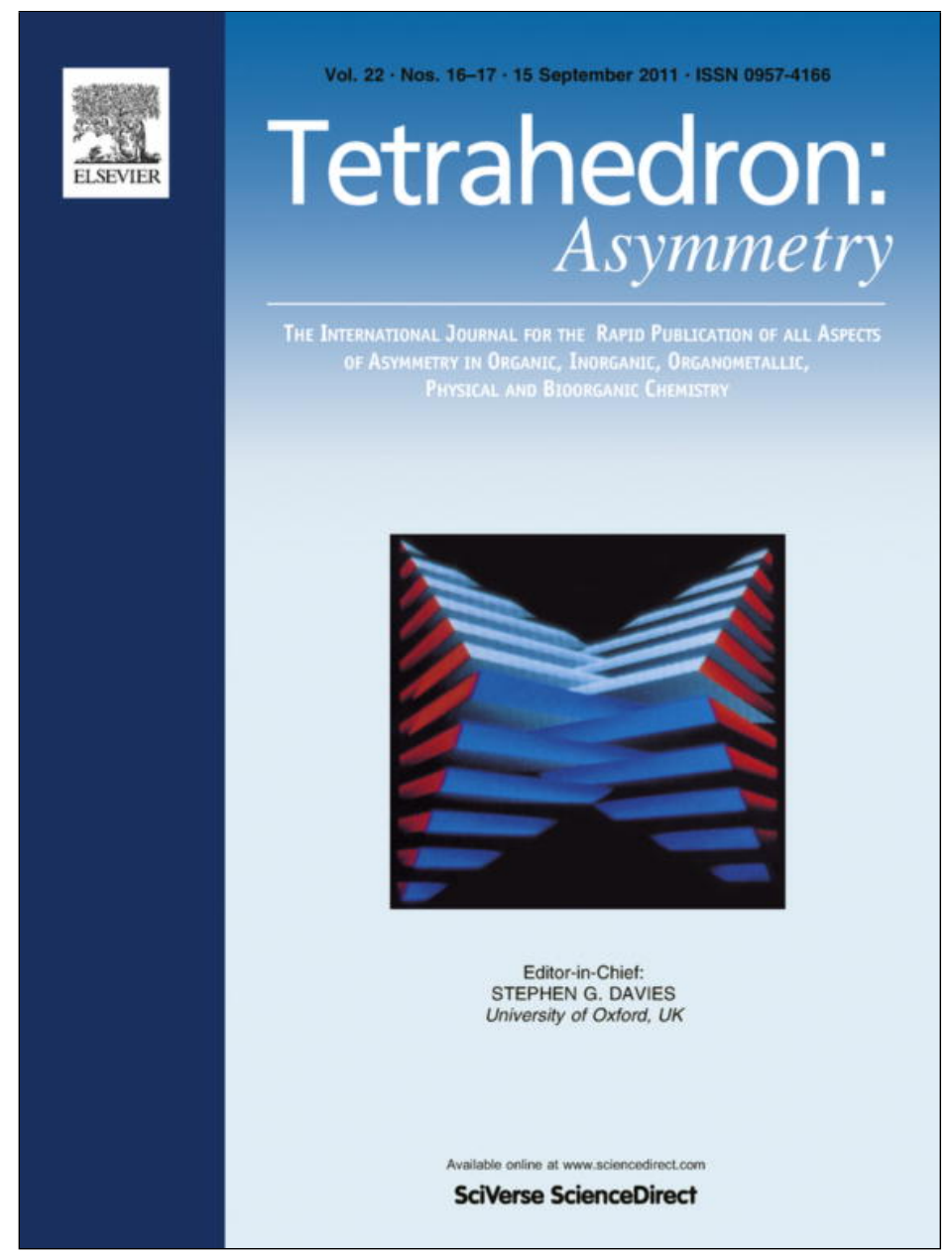

This article appeared in a journal published by Elsevier. The attached copy is furnished to the author for internal non-commercial research and education use, including for instruction at the authors institution and sharing with colleagues.

Other uses, including reproduction and distribution, or selling or licensing copies, or posting to personal, institutional or third party websites are prohibited.

In most cases authors are permitted to post their version of the article (e.g. in Word or Tex form) to their personal website or institutional repository. Authors requiring further information regarding Elsevier's archiving and manuscript policies are encouraged to visit:

http://www.elsevier.com/copyright 


\title{
Asymmetric microbial conversion of $(E)$-2-benzylideneindan-1-one by the filamentous fungi Botrytis cinerea, Trichoderma viride, and Eutypa lata
}

\author{
Cristina Pinedo-Rivilla, Josefina Aleu*, Isidro G. Collado* \\ Departamento de Química Orgánica, Facultad de Ciencias, Universidad de Cádiz, Campus de Excelencia Internacional Agroalimentario, ceiA3, República Saharaui s/n,
} Apdo. 40, 11510 Puerto Real, Cádiz, Spain

\section{A R T I C L E I N F O}

\section{Article history:}

Received 27 July 2011

Accepted 16 September 2011

Available online 18 October 2011

\begin{abstract}
A B S T R A C T
The transformation of (E)-2-benzylideneindan-1-one $\mathbf{1}$ by the filamentous fungi Botrytis cinerea, Trichoderma viride, and Eutypa lata as biocatalysts was studied. The results showed the catalytic potential of these fungi in affording several hydroxylation and reduction products, three of them reported here for the first time. The absolute configuration of enantiomerically pure 2-benzylindane derivatives was determined.
\end{abstract}

(c) 2011 Elsevier Ltd. All rights reserved.

\section{Introduction}

Indanones and indenones are important classes of natural compounds which are useful building blocks in the synthesis of various carbocyclic and heterocyclic molecules of biological importance. These structures can play an important role in medicinal chemistry as they are present in various drugs or pharmaceutical compounds. ${ }^{1}$ Specifically, (E)-2-benzylideneindan-1-one $\mathbf{1}$ has been shown to exhibit cytotoxic activity against murine P388 and L1210 leukaemic cells as well as human Molt 4/C8 and CEM Tlymphocytes. $^{2}$

Several methods for their preparation have been reported, the most classic involving as the first step the synthesis of indan-1one moiety followed by an aldol reaction with the appropriate aldehydes. ${ }^{3}$ Problems may be encountered with chemical methods such as incomplete transformation, moderate enantiomeric purity and the use of toxic reagents. In contrast, biological methods are useful in introducing chemical functions into inaccessible sites of molecules and thereby producing rare structures with a high structural diversity. In most cases, biotransformations occur with high regio- and stereo-specificities in Nature under mild and environmentally friendly reaction conditions. ${ }^{4}$ In this context, the use of microorganisms is advantageous owing to their rapid growth and easy formation of multienzymatic systems.

The biocatalysts used in this paper were filamentous fungi given that are easily available from large-scale cultures. As part of our research programme focusing on the biocatalytic potential of fungi, we herein describe the biotransformation of $(E)$-2-benzyl-

\footnotetext{
* Corresponding authors. Tel.: +34 956 016368; fax: +34 956016193.

E-mail addresses: josefina.aleu@uca.es (J. Aleu), isidro.gonzalez@uca.es (I.G. Collado).
}

ideneindan-1-one 1 by the filamentous fungi Botrytis cinerea, Trichoderma viride, and Eutypa lata.

\section{Results and discussion}

(E)-2-Benzylideneindan-1-one $\mathbf{1}$ was synthesized using the methodology described in the literature. ${ }^{5}$ After purification, indenone 1 was added to cultures of whole cells of the filamentous fungi $B$. cinerea, $T$. viride and $E$. lata to verify the bio-catalytic potential of these fungi in the biotransformation of $\alpha, \beta$-unsaturated ketones.

The fungus $B$. cinerea produced just two compounds, $(R)-2-(p-$ hydroxybenzyl)-7-hydroxyindan-1-one 2 and (S)-2-(p-hydroxybenzyl)indan-1-one 3 (Scheme 1), the latter being reported here for the first time.

Compound 2 was previously reported ${ }^{6}$ as a detoxification product from the biotransformation of anti-( \pm )-2-benzylindan-1-ol anti-( \pm$)-\mathbf{5}$ by $B$. cinerea.

Comparison of the spectroscopic data of compounds $\mathbf{2}$ and $\mathbf{3}$ indicated that $\mathbf{3}$ possessed only a hydroxyl group, a fact corroborated by its HRMS, which was consistent with the molecular formula $\mathrm{C}_{16} \mathrm{H}_{14} \mathrm{O}_{2}$. The appearance of a signal at $156.9 \mathrm{ppm}$ in its ${ }^{13} \mathrm{C}$ NMR spectrum $\left(\mathrm{C}-4^{\prime}\right)$ indicated a hydroxylation according to product 2-(p-hydroxybenzyl)indan-1-one 3. Its absolute configuration was determined by comparison of its specific rotation value $\left([\alpha]_{\mathrm{D}}^{20}=+6,36 \%\right.$ ee) with that of $(R)$-2-benzylindan-1-one $(R)-4$ $\left([\alpha]_{D}^{20}=-197.1,70 \%\right.$ ee $)$, whose absolute configuration was known. ${ }^{6}$ The compounds presented opposite values, indicating the $(S)$-configuration at $\mathrm{C}-2$. Compound $(S)-2-(p$-hydroxybenzyl)indan-1-one $\mathbf{3}$ is reported here for the first time.

The saturated ketone $\mathbf{4}$ and alcohol $\mathbf{5}$ from the reduction of $\mathbf{1}$ (Scheme 2) were isolated from the broths of $T$. viride and E. lata. 


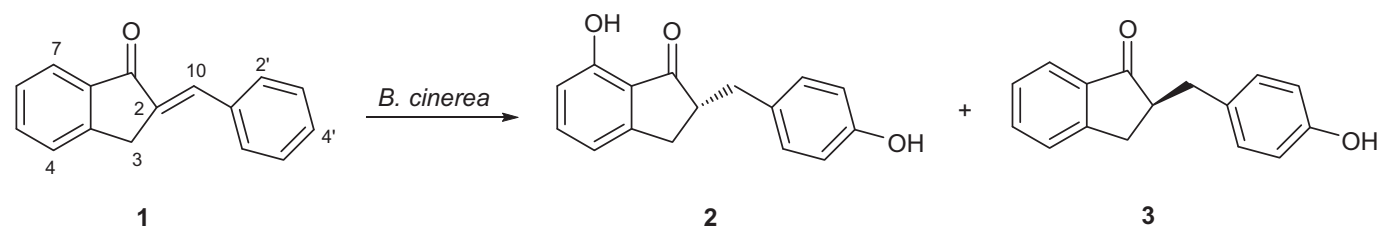

Scheme 1. Biotransformation products by Botrytis cinerea.<smiles>O=C1C(=Cc2ccccc2)Cc2ccccc21</smiles><smiles>O=C1c2ccccc2CC1Cc1ccccc1</smiles>

4<smiles>OC1c2ccccc2CC1Cc1ccccc1</smiles>

Scheme 2. Reduction of (E)-2-benzylideneindan-1-one $\mathbf{1}$.

Spectroscopic data of these products were in agreement with those found in the literature. ${ }^{5,7}$

Benzylindan-1-one 4 was obtained by both fungi with similar yields while ee. $T$. viride afforded the $(R)$-enantiomer with $70 \%$ ee in surface cultures. In shaken cultures, the $(S)$-enantiomer was isolated with a yield of $15 \%$ and $13 \%$ ee. Moreover, the production of $\mathbf{4}$ using E. lata was dependent on the production of other derivatives and therefore yield and ee decreased dramatically over time of fermentation. The absolute configurations of $\mathbf{4}$ were obtained by HPLC analyses with a chiral stationary phase column and comparison of their specific rotation values corresponded with those found in the literature. ${ }^{6}$

2-Benzylindan-1-ol 5 was obtained in shaken cultures only. Thus, $T$. viride gave the syn isomer $(1 R, 2 R)$-2-benzylindan-1-ol $((1 R, 2 R)-5)$ with $100 \%$ de and $99 \%$ ee after 5 days of fermentation. Its absolute configuration was determined from oxidation of the syn isomer $(1 R, 2 R)-\mathbf{5}$ and by HPLC analyses with a chiral stationary phase column to give $(R)-\mathbf{4}$ whose absolute configuration was known. ${ }^{6}$ anti-(1S,2R)-2-Benzylindan-1-ol $((1 S, 2 R)-5)$ was produced by $E$. lata with $100 \%$ de and $95 \%$ ee. ${ }^{6}$

It is interesting to note that E. lata was also able to produce several hydroxylated biotransformation compounds showing the high biocatalytic potential of this fungus: syn-2-(hydroxyphenylmethyl)indan-1-one 6, syn-2-benzyl-2,3-dihydroxyindan-1-one 7, anti2-benzyl-3-hydroxyindan-1-one 8, anti-2-benzylindan-1,2-diol $\mathbf{9}$, 3-hydroxy-2-(hydroxyphenylmethyl)indan-1-one 10, 2-hydroxy2-(hydroxyphenylmethyl)indan-1-one 11, and (E)-2-benzylidene3-hydroxyindan-1-one 12. These products were the result of reductions and/or hydroxylations in the chain and in the five membered ring of (E)-2-benzylideneindan-1-one $\mathbf{1}$.<smiles>O=C1c2ccccc2CC1[C@H](O)c1ccccc1</smiles><smiles>O=C1c2ccccc2[C@H](O)[C@@]1(O)Cc1ccccc1</smiles><smiles>O=C1c2ccccc2[C@H](O)[C@@H]1Cc1ccccc1</smiles><smiles>O[C@H]1c2ccccc2C[C@]1(O)Cc1ccccc1</smiles><smiles>O=C1c2ccccc2C(O)C1C(O)c1ccccc1</smiles><smiles>O=C1c2ccccc2CC1(O)C(O)c1ccccc1</smiles>

10

11<smiles>O=C1C(=Cc2ccccc2)C(O)c2ccccc21</smiles>

12

It was significant that the shaken cultures were the best condition under which to biotransform (E)-2-benzylideneindan-1-one 1 using E. lata as the biocatalyst. syn-2-(Hydroxyphenylmethyl) indan-1-one 6 and anti-2-benzyl-3-hydroxyindan-1-one 8 were previously reported as products from chemical reactions. ${ }^{1,8}$ Compound syn-2-benzyl-2,3-dihydroxyindan-1-one 7 was previously reported $^{6}$ as a detoxification product from the biotransformation of anti-( \pm )-2-benzylindan-1-ol anti-( \pm )-5 by B. cinerea.

The alcohol $\mathbf{6}$ was obtained with 50\% de in favour of the syn configuration in an overall yield of 3\% (relative stereochemistry being assigned by correlation with ${ }^{1} \mathrm{H}$ and ${ }^{13} \mathrm{C}$ NMR data). ${ }^{8}$ The enantiomeric purities of syn and anti alcohol $\mathbf{6}$ were determined by HPLC analyses with a chiral stationary phase column to be $33 \%$ ee and $42 \%$ ee, respectively. This compound was isolated from the eightday broth only suggesting that $\mathbf{6}$ could be transformed into other biotransformation products during the fermentation period.

anti-2-Benzyl-3-hydroxyindan-1-one $\mathbf{8},{ }^{1}$ with $100 \%$ de, was the major compound with the highest enantiomeric excess (46\%) after 8 days of biotransformation. Compound anti-8 was also isolated from the surface culture but the yield was insufficient to calculate the enantiomeric excess.

Compound syn-2-benzyl-2,3-dihydroxyindan-1-one 7 was only isolated from the eight-day broth of the fungus E. lata with $100 \%$ de. The relative stereochemistry was assigned by correlation with ${ }^{1} \mathrm{H}$ and ${ }^{13} \mathrm{C}$ NMR data and comparison of its specific rotation value with that found in the literature. ${ }^{6}$

Compound 9 was isolated as a white solid with the molecular formula $\mathrm{C}_{16} \mathrm{H}_{16} \mathrm{O}_{2}$ determined from its HRMS and corroborated by ${ }^{13} \mathrm{C}$ NMR data. The ${ }^{1} \mathrm{H}$ NMR and ${ }^{13} \mathrm{C}$ NMR spectra were close 
to that of 2-benzylindan-1-ol 5, but the absence of the signal corresponding to $\mathrm{H}-2$ and the appearance of a signal at $83.7 \mathrm{ppm}(\mathrm{C}-2)$ revealed the presence of a tertiary hydroxyl group at $\mathrm{C}-2$ indicating that $\mathbf{9}$ was a diol derivative. The relative stereochemistry of both chiral carbons was determined by nOe experiments. Compound anti-2-benzylindan-1,2-diol 9 was previously reported as a product from chemical transformations ${ }^{9}$ but no spectroscopic data were found for this compound in the literature. These data are reported here for the first time.

Two novel hydroxylated compounds, $\mathbf{1 0}$ and 11, were obtained from the biotransformation of (E)-2-benzylideneindan-1-one 1 by E. lata. Compound $\mathbf{1 0}$ was isolated as a yellow oil with an $\mathrm{M}^{+}$peak at $\mathrm{m} / \mathrm{z} 254$ and featuring ${ }^{13} \mathrm{C}$ NMR spectrum consistent with the molecular formula $\mathrm{C}_{16} \mathrm{H}_{14} \mathrm{O}_{3}$. The ${ }^{1} \mathrm{H}$ NMR spectrum was close to that of 2-benzyl-3-hydroxyindan-1-one 8 , but the appearance of two signals at 70.7 and $74.4 \mathrm{ppm}$ in the ${ }^{13} \mathrm{C}$ NMR spectrum (C-3 and $\mathrm{C}-10$, respectively) and two signals at $4.99(\mathrm{H}-3)$ and $5.03 \mathrm{ppm}(\mathrm{H}-10)$ in the ${ }^{1} \mathrm{H}$ NMR spectrum showed that 10 possessed two secondary hydroxyl groups. Compound 3-hydroxy-2(hydroxylphenylmethyl)indan-1-one $\mathbf{1 0}$ was isolated as a single diastereoisomer, with $100 \%$ de.

The biotransformation of (E)-2-benzylideneindan-1-one 1 by $E$. lata also produced another compound, 11, whose ${ }^{13} \mathrm{C}$ NMR spectrum was consistent with the molecular formula $\mathrm{C}_{16} \mathrm{H}_{14} \mathrm{O}_{3}$. The ${ }^{1} \mathrm{H}$ NMR spectrum was close to that of 2-benzylindan-1-one 4 , but the presence of two signals at 68.6 and $5.45 \mathrm{ppm}$ in the ${ }^{13} \mathrm{C}$ NMR and ${ }^{1} \mathrm{H}$ NMR spectra, respectively, suggests that this compound was hydroxylated at $\mathrm{C}-10$. The absence of the signal corresponding to $\mathrm{H}-2$ showed the presence of a tertiary hydroxyl group at C-2, indicating that $\mathbf{1 1}$ was a diol derivative. Compound 2-hydroxy-2-(hydroxyphenylmethyl)indan-1-one $\mathbf{1 1}$ was obtained with $100 \%$ de.

Compounds 3-hydroxy-2-(hydroxylphenylmethyl)indan-1-one 10 and 2-hydroxy-2-(hydroxyphenylmethyl)indan-1-one $\mathbf{1 1}$ are reported here for the first time.

(E)-2-Benzylidene-3-hydroxyindan-1-one 12, obtained only under shaken conditions with $95 \%$ ee, was previously reported as a product from chemical reactions and its spectroscopic data coincided with those found in the literature. ${ }^{10}$ This is the only product with a double bond at $\mathrm{C}-2 / \mathrm{C}-10$ isolated from the $E$. lata broth, whose structure could be explained by direct hydroxylation from (E)-2-benzylideneindan-1-one $\mathbf{1}$ at C-3.

The stereoselectivity of these biotransformation compounds obtained from E. lata was very high, giving only one diastereoisomer but in the absence of at least one enantiomer of known configuration, we had no way of determining which enantiomer was which.

\section{Conclusions}

In summary, the studies described above have demonstrated the biocatalytic potential of the filamentous fungi $B$. cinerea, $T$. vir$i d e$, and E. lata to obtain biotransformation compounds with high enantiomeric purity from (E)-2-benzylideneindan-1-one $\mathbf{1}$.

The main reaction paths involved reduction and hydroxylation reactions at several positions. Thus, $B$. cinerea gave $(R)-2-(p-$ hydroxybenzyl)indan-1-one $\mathbf{2}^{6}$ and $(S)$-2-( $p$-hydroxybenzyl)-7hydroxyindan-1-one $\mathbf{3}$, reported here for the first time.

(E)-2-Benzylideneindan-1-one $\mathbf{1}$ was reduced to its corresponding saturated ketone 2-benzylindan-1-one $\mathbf{4}$ and saturated alcohol 2-benzylindan-1-ol 5 by E. lata and T. viride. Thus, T. viride afforded compound 4 with a maximum yield of $15 \%$ after 10 days of fermentation and $70 \%$ ee after 5 days from surface cultures. E. lata gave ketone 4 with a yield of $13 \%$ and $58 \%$ ee after 8 days of biotransformation and from shaken cultures. The predominant enantiomer was $R$, although the enantiomeric excess decreased dramatically leading to an inversion of the configuration. E. lata and $T$. viride exhibited high stereoselectivity giving the anti isomer (1S,2R)-2-benzylindan-1-ol (1S,2R)-5 with >99\% de and 95\% ee, and the syn isomer $(1 R, 2 R)$-2-benzylindan-1-ol $(1 R, 2 R)-5$ with $>99 \%$ de and $99 \%$ ee, respectively.

$E$. lata was a very effective biocatalyst for (E)-2-benzylideneindan-1-one 1 giving rise to several compounds, two of them reported here for the first time. The high stereospecificity observed for Eutypa and its ability to generate novel compounds indicates that this fungus could be considered as a potential biocatalyst.

\section{Experimental}

\subsection{General}

Optical rotations were determined with a Perkin-Elmer 241 polarimeter. IR spectra were recorded on a Mattson Genesis spectrophotometer, series FTIR. ${ }^{1} \mathrm{H}$ and ${ }^{13} \mathrm{C}$ NMR measurements were obtained on Varian Unity 400 and Varian Unity 600 NMR spectrometers with $\mathrm{SiMe}_{4}$ as the internal reference. Mass spectra were recorded on a GC-MS Thermoquest spectrometer (model: Voyager), and a VG Autospec-Q spectrometer. HPLC was performed with a Hitachi/Merck L-6270 apparatus equipped with a UV-VIS detector (L 6200) and a differential refractometer detector (RI71). TLC was performed on Merck Kiesegel $60 \mathrm{~F}_{254}, 0.2 \mathrm{~mm}$ thick. Silica gel (Merck) was used for column chromatography. Purification by means of HPLC was performed with a silica gel column (Hibar $60,7 \mathrm{~m}, 1 \mathrm{~cm}$ wide, $25 \mathrm{~cm}$ long). Chemicals were supplied by Fluka and Aldrich. All solvents used were freshly distilled. Enantiomeric excesses were determined by means of HPLC analyses on a chiral column (Chiralcel OD, Daicel, Japan): $254 \mathrm{~nm}$.

\subsection{Microorganism cultures}

The culture of $B$. cinerea employed in this work, $B$. cinerea UCA992, was obtained from grapes from the Domecq vineyard, Jerez de la Frontera, Cádiz, Spain. This culture of B. cinerea is deposited in the Universidad de Cadiz, Facultad de Ciencias, Mycological Herbarium Collection (UCA). The E. lata and T. viride cultures used in this research were obtained from the 'Colección Española de Cultivos Tipo' (CECT), Facultad de Biología, Universidad de Valencia, Spain, where cultures of these strains are kept on deposit.

\subsection{General culture conditions}

Fungi were grown at $25^{\circ} \mathrm{C}$ on a Czapeck-Dox medium (B. cinerea UCA 992) or on a PDB medium (E. lata and T. viride) $(150 \mathrm{~mL}$ per bottle and $200 \mathrm{~mL}$ per flask). The shaken cultures were incubated in an orbital shaker at $140 \mathrm{rpm}$. The substrate was dissolved in ethanol $(200 \mu \mathrm{L})$ and then distributed in Roux bottles or flasks (150 ppm per flask). Fermentation continued for a further period of time after which the mycelium was filtered and then washed with brine and ethyl acetate. The broth was extracted three times with ethyl acetate and the extract dried over anhydrous sodium sulfate. The solvent was then evaporated and the residue chromatographed, first on a silica gel column and then by HPLC with an increasing gradient of ethyl acetate to petroleum ether.

\subsection{Biotransformation of (E)-2-benzylideneindan-1-one 1}

\subsubsection{Biotransformation by $B$. cinerea}

(a) Surface culture. (E)-2-Benzylideneindan-1-one 1 was dissolved in ethanol and then distributed in 12 Roux bottles after 2 days growth. The fermentation was allowed to continue for 5 more days in six of the bottles and 10 more days in the other six. Chromatography of the extract fermented for 5 days gave $(E)-2$ - 
benzylideneindan-1-one 1 (9 mg), and $(R)$-2-( $p$-hydroxybenzyl)-7hydroxyindan-1-one $2(10 \mathrm{mg})\left([\alpha]_{\mathrm{D}}^{20}=-3.8(\right.$ c $0.1, \mathrm{MeOH}), 11 \%$ ee). Chromatography of the extract fermented for 10 days gave (E)-2-benzylideneindan-1-one 1 (10 mg), and $(R)$-2-( $p$-hydroxybenzyl)-7-hydroxyindan-1-one 2 (15 mg) $\left(\left([\alpha]_{\mathrm{D}}^{20}=-6.5\right.\right.$ (c 0.1 , $\mathrm{MeOH}), 19 \%$ ee). (b) Shaken culture. (E)-2-Benzylideneindan-1-one 1 was dissolved in ethanol and then distributed in 10 flasks $(500 \mathrm{~mL})$ in an orbital shaker after 2 days growth. The fermentation was allowed to continue for 5 more days in five of the flasks and 10 more days in the other five. Chromatography of the extract fermented for 5 days gave (E)-2-benzylideneindan-1-one $1(4 \mathrm{mg})$ and $(R)$-2-(p-hydroxybenzyl)-7-hydroxyindan-1-one 2 (17 mg) $\left(\left([\alpha]_{\mathrm{D}}^{20}=-4.0(c 0.1, \mathrm{MeOH}), 12 \%\right.\right.$ ee $)$. Chromatography of the extract fermented for 10 days gave $(E)$-2-benzylideneindan-1-one 1 $(14 \mathrm{mg})$, and $(S)$-2-( $p$-hydroxybenzyl)indan-1-one 3 (50 mg) $\left(\left([\alpha]_{\mathrm{D}}^{20}=+6.0(\right.\right.$ c $0.1, \mathrm{MeOH}), 36 \%$ ee $)$.

\subsubsection{Biotransformation by $T$. viride}

(a) Surface culture. (E)-2-Benzylideneindan-1-one 1 was dissolved in ethanol and then distributed in 12 Roux bottles after 2 days growth. The fermentation was allowed to continue for 5 more days in six of the bottles and 10 more days in the other six. Chromatography of the extract fermented for 5 days gave $(E)-2$ benzylideneindan-1-one 1 (16 mg), $(R)$-2-benzylindan-1-one $(R)$ $4(2 \mathrm{mg})\left(\left([\alpha]_{\mathrm{D}}^{20}=-197.1\left(\mathrm{c} 0.1, \mathrm{CHCl}_{3}\right), 86 \%\right.\right.$ ee $)$, and syn-2-benzylindan-1-ol $\mathbf{5}$ (traces). Chromatography of the extract fermented for 10 days gave $(E)$-2-benzylideneindan-1-one $1(2 \mathrm{mg}),(R)-2$ benzylindan-1-one $(R)-4(3 \mathrm{mg})\left(\left([\alpha]_{\mathrm{D}}^{20}=-162.0\right.\right.$ (c $\left.0.1, \mathrm{CHCl}_{3}\right)$, 70\% ee), and syn-2-benzylindan-1-ol $\mathbf{5}$ (traces). (b) Shaken culture. (E)-2-Benzylideneindan-1-one $\mathbf{1}$ was dissolved in ethanol and then distributed in 10 flasks $(500 \mathrm{~mL})$ in an orbital shaker after 2 days growth. The fermentation was allowed to continue for 5 more days in five of the flasks and 10 more days in the other five. Chromatography of the extract fermented for 5 days gave $(E)$-2-benzylideneindan-1-one 1 (22 mg), $(R)$-2-benzylindan-1-one $(R)-4(3.5 \mathrm{mg})$ $\left(\left([\alpha]_{\mathrm{D}}^{20}=-179.0\right.\right.$ (c $\left.0.1, \mathrm{CHCl}_{3}\right), 78 \%$ ee), and $(1 R, 2 R)$-2-benzylindan-1-ol $(1 R, 2 R)-5$ (3 mg) $\left([\alpha]_{\mathrm{D}}^{25}=-5.0^{\circ}\left(\right.\right.$ c $\left.0.1, \mathrm{CHCl}_{3}\right), 100 \% \mathrm{de}$, $99 \%$ ee). Chromatography of the extract fermented for 10 days gave (E)-2-benzylideneindan-1-one 1 (3 mg), (S)-2-benzylindan-1-one $(S)-4(20 \mathrm{mg})\left(\left([\alpha]_{\mathrm{D}}^{20}=+37.1\left(c \mathrm{c} 0.1, \mathrm{CHCl}_{3}\right), 16 \% \mathrm{ee}\right),(1 R, 2 R)-2\right.$-benzylindan-1-ol $(1 R, 2 R)-5(8 \mathrm{mg})\left(\left([\alpha]_{\mathrm{D}}^{20}=-4.0\left(\right.\right.\right.$ c $\left.0.1, \mathrm{CHCl}_{3}\right), 79 \%$ ee), and $(1 S, 2 R)-2$-benzylindan-1-ol $(1 S, 2 R)-5 \quad(2 \mathrm{mg}) \quad\left(\left([\alpha]_{\mathrm{D}}^{20}=\right.\right.$ -7.2 (c $\left.0.1, \mathrm{CHCl}_{3}\right), 64 \%$ ee).

\subsubsection{Biotransformation by Eutypa lata}

(a) Surface culture. (E)-2-Benzylideneindan-1-one 1 was dissolved in ethanol and then distributed in 12 Roux bottles after 7 days growth. The fermentation was allowed to continue for 8 more days in six of the bottles and 15 more days in the other six. Chromatography of the extract fermented for 8 days gave $(E)-2-$ benzylideneindan-1-one $\mathbf{1}$ (36.3 mg), 2-benzylindan-1-one $\mathbf{4}$ (traces) and anti-2-benzylindan-1,2-diol 9 (1.2 mg) $\left(\left([\alpha]_{\mathrm{D}}^{20}=\right.\right.$ -14.0 ( $c 0.1, \mathrm{CHCl}_{3}$ ), $100 \%$ de, $16 \%$ ee). Chromatography of the extract fermented for 15 days gave $(E)$-2-benzylideneindan-1-one 1 (34.3 mg), $(R)$-2-benzylindan-1-one $(R)-\mathbf{4}(3 \mathrm{mg})\left(\left([\alpha]_{\mathrm{D}}^{20}=-48.6\right.\right.$ (c $\left.0.1, \mathrm{CHCl}_{3}\right), 21 \%$ ee), and anti-2-benzylindan-1-ol 5 (traces). (b) Shaken culture. (E)-2-Benzylideneindan-1-one $\mathbf{1}$ was dissolved in ethanol and then distributed in 10 flasks $(500 \mathrm{~mL})$ in an orbital shaker after 7 days growth. The fermentation was allowed to continue for 8 more days in five of the flasks and 15 more days in the other five. Chromatography of the extract fermented for 8 days gave (E)-2-benzylideneindan-1-one $1(23 \mathrm{mg}),(R)$-2-benzylindan1-one $(R)-4$ (15 mg) $\left(\left([\alpha]_{\mathrm{D}}^{20}=-166.3\left(c \quad 0.1, \mathrm{CHCl}_{3}\right), 72 \%\right.\right.$ ee), $(1 S, 2 R)-2$-benzylindan-1-ol $(1 S, 2 R)-5(1.8 \mathrm{mg})\left(\left([\alpha]_{\mathrm{D}}^{20}=-11.0(c\right.\right.$ $\left.0.1, \mathrm{CHCl}_{3}\right), 100 \%$ de, $95 \%$ ee), syn-2-(hydroxylphenylmethyl)indan-1-one 6 (3 mg) $\left(\left([\alpha]_{\mathrm{D}}^{20}=+88.0\left(\right.\right.\right.$ c $\left.0.1, \mathrm{CHCl}_{3}\right)$, syn/anti
75:25, syn 33\% ee, anti $42 \%$ ee), syn-2-benzyl-2,3-dihydroxyindan-1-one $7(1.7 \mathrm{mg})\left(\left([\alpha]_{\mathrm{D}}^{20}=-17.0\left(\right.\right.\right.$ c $\left.0.1, \mathrm{CHCl}_{3}\right), 26 \%$ ee, $100 \%$ de), anti-2-benzyl-3-hydroxyindan-1-one $8(24 \mathrm{mg}) \quad\left(\left([\alpha]_{\mathrm{D}}^{20}=\right.\right.$ -38.0 ( c $0.1, \mathrm{CHCl}_{3}$ ), 100\% de, 46\% ee), anti-2-benzylindan-1,2-diol $9(15 \mathrm{mg})\left(\left([\alpha]_{\mathrm{D}}^{20}=-15.0\right.\right.$ (c $\left.0.1, \mathrm{CHCl}_{3}\right), 100 \%$ de, $18 \%$ ee), 3-hydroxy-2-(hydroxyphenylmethyl)indan-1-one $\quad \mathbf{1 0} \quad(8 \mathrm{mg}) \quad\left(\left([\alpha]_{\mathrm{D}}^{20}=\right.\right.$ -50.6 ( c $\left.0.1, \mathrm{CHCl}_{3}\right), 100 \%$ de, $60 \%$ ee), and 2-hydroxy-2-(hydroxyphenylmethyl)indan-1-one $11(2 \mathrm{mg})\left(\left([\alpha]_{\mathrm{D}}^{20}=-28.0^{\circ} \quad\right.\right.$ (c 0.1 , $\left.\mathrm{CHCl}_{3}\right), 100 \%$ de, $98 \%$ ee). Chromatography of the extract fermented for 15 days gave $(E)$-2-benzylideneindan-1-one 1 (9 mg), $(S)$-2benzylindan-1-one $(S)-4(10 \mathrm{mg})\left([\alpha]_{\mathrm{D}}^{20}=+23.5\right.$ (c $\left.0.1, \mathrm{CHCl}_{3}\right)$, $10 \%$ ee), (1S,2R)-2-benzylindan-1-ol $(1 S, 2 R)-5 \quad(5 \mathrm{mg}) \quad\left(\left([\alpha]_{\mathrm{D}}^{20}=\right.\right.$ -11.0 ( c $\left.0.1, \mathrm{CHCl}_{3}\right), 95 \%$ ee), (1R,2R)-2-benzylindan-1-ol $(1 R, 2 R)$ 5 (traces), syn-2-(hydroxylphenylmethyl)indan-1-one 6 (traces), anti-2-benzyl-3-hydroxyindan-1-one $8(30 \mathrm{mg})\left(\left([\alpha]_{\mathrm{D}}^{20}=-15.6(c\right.\right.$ $\left.0.1, \mathrm{CHCl}_{3}\right), 100 \%$ de, $19 \%$ ee), anti-2-benzylindan-1,2-diol 9 $(8 \mathrm{mg})\left(\left([\alpha]_{\mathrm{D}}^{20}=-7.07 .0\left(\right.\right.\right.$ c $\left.0.1, \mathrm{CHCl}_{3}\right), 100 \%$ de, 7\% ee), 2-hydroxy-2-(hydroxyphenylmethyl)indan-1-one $11(5 \mathrm{mg})\left(\left([\alpha]_{\mathrm{D}}^{20}=-6.4\right.\right.$ (c $\left.0.1, \mathrm{CHCl}_{3}\right), 100 \%$ de, $22 \%$ ee), and (E)-2-benzylidene-3-hydroxyindan-1-one $12(1.5 \mathrm{mg})\left(\left([\alpha]_{\mathrm{D}}^{20}=+62.5\left(\right.\right.\right.$ c $\left.0.1, \mathrm{CHCl}_{3}\right), 95 \%$ ee $)$.

\subsection{Oxidation of $(1 R, 2 R)-2$-benzylindan-1-ol $(1 R, 2 R)-5$}

The alcohol (1R,2R)-2-benzylindan-1-ol (1R,2R)-5 (5 mg, $0.022 \mathrm{mmol}$ ) was oxidised with manganese(IV) oxide (1.5 equiv) in methylene chloride solution $(1.5 \mathrm{~mL})$ at room temperature. After purification using a silica gel column, eluting with hexane/ethyl acetate $(9: 1)$, the derivative $(R)-(-)$-2-benzylindan-1-one $(R)-4$ (98\% yield) was afforded.

\subsection{1. $(R)$-2-( $p$-Hydroxybenzyl)-7-hydroxyindan-1-one $\mathbf{2}^{6}$}

Obtained as a yellow oil, $\left([\alpha]_{\mathrm{D}}^{20}=-6.5(c 0.1, \mathrm{MeOH}), 19 \%\right.$ ee. HPLC ( $n$-hexane/i-PrOH 97:3, $0.5 \mathrm{~mL} / \mathrm{min}$ ): $t_{\mathrm{R}} 30.1 \mathrm{~min}(R)$ and $50.9 \min (S)$.

\subsection{2. ( $($ )-2-(p-Hydroxybenzyl)indan-1-one 3}

Obtained as a yellow oil, $\left([\alpha]_{\mathrm{D}}^{20}=+6.0(\right.$ c $0.1, \mathrm{MeOH}), 36 \%$ ee. IR $v_{\max }$ (film): $3344,1688 .{ }^{1} \mathrm{H}$ NMR $\left(400 \mathrm{MHz}, \mathrm{CD}_{3} \mathrm{OD}\right): \delta 2.70$ (ddd, $1 \mathrm{H}, J=2.0,9.7,13.8 \mathrm{~Hz}, \mathrm{H}-10), 2.82(\mathrm{dt}, 1 \mathrm{H}, J=3.2,16.9 \mathrm{~Hz}, \mathrm{H}-3)$, $2.99(\mathrm{~m}, 1 \mathrm{H}, \mathrm{H}-2), 3.09(\mathrm{dd}, 1 \mathrm{H}, J=7.3,16.9 \mathrm{~Hz}, \mathrm{H}-3), 3.19(\mathrm{dd}, 1 \mathrm{H}$, $J=4.4,13.8 \mathrm{~Hz}, \mathrm{H}-10), 6.66$ (d, 2H, $J=8.5 \mathrm{~Hz}, \mathrm{H}-3, \mathrm{H}-5), 6.67(\mathrm{~m}$,

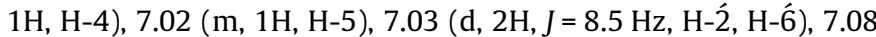
$(\mathrm{dt}, 1 \mathrm{H}, J=3.2,8.2 \mathrm{~Hz}, \mathrm{H}-6), 7.27$ (dd, $1 \mathrm{H}, J=3.5,8.2 \mathrm{~Hz}, \mathrm{H}-7) .{ }^{13} \mathrm{C}$ NMR (100 MHz, CD $\mathrm{CD}_{3} \mathrm{OD}$ ): $\delta 32.1$ (t, C-3), 37.2 (t, C-10), 51.2 (d, C-2), 108.9 (d, C-5), 116.2 (d, C-3, C-5), 121.2 (d, C-4), 125.1 (d, C-6), 128.5 (d, C-7), 130.9 (d, C-2́, C-6), 131.5 (s, C-1́), 146.9 (s, C-9), 156.9 (s, C-4), 158.5 (s, C-8), 210.7 (s, C-1). MS (m/z, \%): $238\left(\mathrm{M}^{+}\right.$, 0.3), 148 (33), 107 (100), 77 (15). HRMS (EI, $70 \mathrm{eV):} \mathrm{calcd} \mathrm{for}$ $\mathrm{C}_{16} \mathrm{H}_{14} \mathrm{O}_{2}: 238.09938[\mathrm{M}]^{+}$; found: 238.0971. HPLC ( $n$-hexane $/ i-$ PrOH 97:3, $0.5 \mathrm{~mL} / \mathrm{min}): t_{\mathrm{R}} 21.9 \mathrm{~min}(R)$ and $33.9 \mathrm{~min}(S)$.

\subsubsection{2-Benzylindan-1-one 4}

Obtained as a colourless oil. Product structure assignments were done attending to the spectroscopic data reported in the literature. ${ }^{5}$ HPLC ( $n$-hexane/i-PrOH 9:1, $0.4 \mathrm{~mL} / \mathrm{min}$ ): $t_{\mathrm{R}} 17.0 \mathrm{~min}(R)$ and $18.4 \min (S)$.

\subsubsection{2-Benzylindan-1-ol 5}

Obtained as a white solid. Product structure assignments were done attending to the spectroscopic data reported in literature. ${ }^{7}$ HPLC ( $n$-hexane/i-PrOH 9:1, $0.4 \mathrm{~mL} / \mathrm{min}$ ): $t_{\mathrm{R}}$ (anti): $14 \mathrm{~min}(S, R)$ and $30 \mathrm{~min}(R, S) ; t_{\mathrm{R}}(s y n): 18.7 \mathrm{~min}(R, R)$ and $23.1 \mathrm{~min}(S, S)$.

\subsection{5. syn-2-(Hydroxyphenylmethyl)indan-1-one 6}

Obtained as a colourless oil, $\left([\alpha]_{\mathrm{D}}^{20}=+88.0\left(\right.\right.$ c $\left.0.1, \mathrm{CHCl}_{3}\right)$, syn/ anti $75: 25$, syn $33 \%$ ee, anti $42 \%$ ee as determined by ${ }^{1} \mathrm{H}$ NMR spec- 
troscopy. HPLC (n-hexane/i-PrOH 9:1, $0.6 \mathrm{~mL} / \mathrm{min}): t_{\mathrm{R}}$ (anti): 36.3 min (minor), $41.0 \mathrm{~min}$ (major); $t_{\mathrm{R}}$ (syn): $45.9 \mathrm{~min}$ (minor), $58.2 \mathrm{~min}$ (major).

\subsection{6. syn-2-Benzyl-2,3-dihydroxyindan-1-one 7}

Obtained as a colourless oil, $\left([\alpha]_{\mathrm{D}}^{20}=-17.0\left(\mathrm{c} 0.1, \mathrm{CHCl}_{3}\right), 26 \%\right.$ ee, $100 \%$ de as determined by ${ }^{1} \mathrm{H}$ NMR spectroscopy. HPLC syn-isomer ( $n$-hexane/i-PrOH 95:5, $0.8 \mathrm{~mL} / \mathrm{min}$ ): $t_{\mathrm{R}} 16.8 \mathrm{~min}$ (major) and 23.8 min (minor).

\subsection{7. anti-2-Benzyl-3-hydroxyindan-1-one 8}

Obtained as a colourless oil, $\left([\alpha]_{\mathrm{D}}^{20}=-38.0\left(c 0.1, \mathrm{CHCl}_{3}\right), 46 \%\right.$ ee, $100 \%$ de as determined by ${ }^{1} \mathrm{H}$ NMR spectroscopy. HPLC anti-isomer ( $n$-hexane $/ i$-PrOH 9:1, $0.6 \mathrm{~mL} / \mathrm{min}$ ): $t_{\mathrm{R}} 13.7 \mathrm{~min}$ (major) and 14.4 min (minor).

\subsection{8. anti-2-Benzylindan-1,2-diol $9^{9}$}

Obtained as a white solid. Mp $120-121^{\circ} \mathrm{C}$. $\left([\alpha]_{\mathrm{D}}^{20}=-15.0\right.$ (c 0.1, $\left.\mathrm{CHCl}_{3}\right), 100$ de, $93 \%$ ee. IR $v_{\max }$ (film): $3373,2359 .{ }^{1} \mathrm{H} \mathrm{NMR}$ $\left(400 \mathrm{MHz}, \mathrm{CDCl}_{3}\right): \delta 2.58(\mathrm{~d}, 1 \mathrm{H}, J=16.1 \mathrm{~Hz}, \mathrm{H}-3), 2.79(\mathrm{~d}, 1 \mathrm{H}$, $J=13.5 \mathrm{~Hz}, \mathrm{H}-10), 3.10$ (d, $\left.1 \mathrm{H}, J=16.1 \mathrm{~Hz}, \mathrm{H}-3^{\prime}\right), 3.11$ (d, $1 \mathrm{H}$, $\left.J=13.5 \mathrm{~Hz}, \mathrm{H}-10^{\prime}\right), 4.69$ (d, $\left.1 \mathrm{H}, J=5.3 \mathrm{~Hz}, \mathrm{H}-1\right), 7.14$ (m, 4H, Harom), 7.24 (m, 4H, Harom), $7.30(\mathrm{~d}, 1 \mathrm{H}, J=7.0 \mathrm{~Hz}$, Harom $) .{ }^{13} \mathrm{C}$ NMR (100 MHz, $\left.\mathrm{CDCl}_{3}\right): \delta 40.0(\mathrm{t}, \mathrm{C}-10), 42.8(\mathrm{t}, \mathrm{C}-3), 81.9(\mathrm{~d}, \mathrm{C}-$ 1), 83.7 (s, C-2), 125.0 (d, Carom), 125.4 (d, Carom), 126.7 (d, Carom), 127.2 (d, Carom), 128.5 (d, C-3', C-5'), 129.0 (d, Carom), 130.5 (d, C-2', C-6'), 137.1 (s, C-1'), 141.0 (s, C-9), 143.0 (s, C-8). MS (m/z, \%): $240\left(\mathrm{M}^{+}, 18\right), 222$ (30), 148 (100), 91 (90); HRMS (EI, $\left.70 \mathrm{eV}\right)$ : calcd for $\mathrm{C}_{16} \mathrm{H}_{16} \mathrm{O}_{2}: 240.1150$ [M] ${ }^{+}$; found: 240.1149 . HPLC ( $n$-hexane/i-PrOH 9.5:0.5, $1 \mathrm{~mL} / \mathrm{min}$ ): $t_{\mathrm{R}} 16.9 \mathrm{~min}$ (minor) and $18.6 \mathrm{~min}$ (major).

\subsubsection{3-Hydroxy-2-(hydroxylphenylmethyl)indan-1-one 10}

Obtained as a yellow oil, $\left([\alpha]_{\mathrm{D}}^{20}=-50.6\left(\mathrm{c} 0.1, \mathrm{CHCl}_{3}\right), 100 \%\right.$ de, $60 \%$ ee. IR $v_{\max }$ (film): $3388,2927,1693,1051 .{ }^{1} \mathrm{H}$ NMR $(400 \mathrm{MHz}$, $\left.\mathrm{CDCl}_{3}\right): \delta 2.99(\mathrm{dd}, 1 \mathrm{H}, J=4.1,9.4 \mathrm{~Hz}, \mathrm{H}-2), 4.99(\mathrm{~d}, 1 \mathrm{H}, J=4.1 \mathrm{~Hz}$, $\mathrm{H}-3$ ), 5.03 (d, 1H, J=9.4 Hz, H-10), 7.47 (m, 6H, Harom), 7.61 (d, $1 \mathrm{H}, J=7.6 \mathrm{~Hz}$, Harom), 7.68 (t, 1H, J = 7.3 Hz, Harom), 7.77 (d, $1 \mathrm{H}$, $J=7.6 \mathrm{~Hz}$, Harom). ${ }^{13} \mathrm{C}$ NMR $\left(100 \mathrm{MHz}, \mathrm{CDCl}_{3}\right): \delta 64.3$ (d, C-2), 70.7 (d, C-3), 74.4 (d, C-10), 123.4 (d, Carom), 125.6 (d, Carom), 126.8 (d, C-2', C-6'), 128.7 (d, Carom), 129.0 (d, C-3', C-5'), 129.5 (d, Carom), 135.2 (s, Carom), 135.9 (d, Carom), 140.8 (s, C-1'),
153.4 (s, Carom), 204.8 (s, C-1). MS (m/z, \%): $254\left(\mathrm{M}^{+}, 45\right), 236$ (17), 147 (100); HRMS (EI, $70 \mathrm{eV}$ ): calcd for $\mathrm{C}_{16} \mathrm{H}_{14} \mathrm{O}_{3}: 254.0943$ $[\mathrm{M}]^{+}$; found: 254.0974. HPLC (n-hexane/i-PrOH 9.8:0.2, $1 \mathrm{~mL} /$ $\min$ ): $t_{\mathrm{R}} 20.0 \mathrm{~min}$ (minor) and $32.4 \mathrm{~min}$ (major).

\subsubsection{2-Hydroxy-2-(hydroxylphenylmethyl)indan-1-one 11}

Obtained as a colourless oil, $\left([\alpha]_{\mathrm{D}}^{20}=-28.0\left(\right.\right.$ c $\left.0.1, \mathrm{CHCl}_{3}\right), 100 \%$ de, $98 \%$ ee. IR $v_{\max }$ (film): $3417,2925,1631 .{ }^{1} \mathrm{H}$ NMR $(400 \mathrm{MHz}$, $\left.\mathrm{CDCl}_{3}\right): \delta 2.63(\mathrm{dd}, 1 \mathrm{H}, J=3.0 \mathrm{~Hz}, 18.8 \mathrm{~Hz}, \mathrm{H}-3), 3.13(\mathrm{dd}, 1 \mathrm{H}$, $\left.J=6.7 \mathrm{~Hz}, 18.8 \mathrm{~Hz}, \mathrm{H}-3^{\prime}\right), 5.45$ (dd, $1 \mathrm{H}, J=3.0 \mathrm{~Hz}, 6.7 \mathrm{~Hz}, \mathrm{H}-10$ ), 7.49 ( $\mathrm{m}, 4 \mathrm{H}$, Harom), $7.70(\mathrm{~m}, 4 \mathrm{H}$, Harom), $7.75(\mathrm{~d}, 1 \mathrm{H}, J=7.6 \mathrm{~Hz}$, $\mathrm{H}-7) .{ }^{13} \mathrm{C}$ NMR $\left(100 \mathrm{MHz}, \mathrm{CDCl}_{3}\right): \delta 47.2(\mathrm{t}, \mathrm{C}-3), 68.6(\mathrm{~d}, \mathrm{C}-10)$, 123.3 (d, C-7), 125.8 (d, Carom), 126.8 (d, Carom), 129.1 (d, Carom), 129.5 (d, C-3', C-5'), 130.1 (d, Carom), 134.4 (s, Carom), 135.3 (d, C2', C-6'), 136.4 (s, Carom), 154.9 (s, Carom), 202.0 (s, C-1). MS (m/ $z, \%): 254\left(\mathrm{M}^{+}, 40\right), 236$ (100), 218 (18), 91 (43); HRMS (EI, $\left.70 \mathrm{eV}\right)$ : calcd for $\mathrm{C}_{16} \mathrm{H}_{14} \mathrm{O}_{3}$ : 254.0943; found: 254.1086 [M] ${ }^{+}$. HPLC ( $n$-hexane/i-PrOH 9.5:0.5, $0.8 \mathrm{~mL} / \mathrm{min}$ ): $t_{\mathrm{R}} 19.2 \mathrm{~min}$ (major) and $25.7 \mathrm{~min}$ (minor).

\subsubsection{1. (E)-2-Benzylidene-3-hydroxyindan-1-one $12^{10}$}

Obtained as a white solid. Mp $186^{\circ} \mathrm{C}$. $\left([\alpha]_{\mathrm{D}}^{20}=+62.5\right.$ (c 0.1 , $\mathrm{CHCl}_{3}$ ), 95\% ee. HPLC ( $n$-hexane/i-PrOH 9.8:0.2, $\left.0.8 \mathrm{~mL} / \mathrm{min}\right): t_{\mathrm{R}}$ $23.6 \mathrm{~min}$ (minor) and $25.4 \mathrm{~min}$ (major).

\section{References}

1. Petrignet, J.; Roisnel, T.; Greé, R. Chem. Eur. J. 2007, 13, 7374-7384.

2. Dimmock, J. R.; Kandepu, N. M.; Nazarali, A. J.; Kowalchuk, T. P.; Motaganahalli, N.; Quail, J. W.; Mykytiuk, P. A.; Audette, G. F.; Prasad, L.; Perjesi, P.; Allen, T. M.; Santos, Ch. L.; Szydlowski, J.; De Clercq, E.; Balzarini, J. J. Med. Chem. 1999, 42, 1358-1366.

3. Basavaiah, D.; Reddy, R. M. Tetrahedron Lett. 2001, 42, 3025-3027.

4. Alcalde, M.; Ferrer, M.; Plou, F. J.; Ballesteros, A. Trends Biotechnol. 2006, 24, 281.

5. Martínez, A.; Fernández, M.; Estévez, J.; Estévez, R.; Castedo, L. Tetrahedron 2005, 61, 485-492.

6. Pinedo-Rivilla, C.; Aleu, J.; Grande Benito, M.; Collado, I. G. Org. Biomol. Chem. 2010, 8, 3784-3789.

7. Aleu, J.; Fronza, G.; Fuganti, V. P.; Serra, S. Tetrahedron: Asymmetry 1998, 9, 1589-1596.

8. Orito, Y.; Hashimoto, S.; Ishizuka, T.; Nakajima, M. Tetrahedron 2006, 62, 390400.

9. Cromwell, N. H.; Martin, J. L. J. Org. Chem. 1968, 33, 1890-1894.

10. Yoshizawa, K.; Shioiri, T. Tetrahedron 2007, 63, 6259-6286. 